ҚАЗАҚСТАН РЕСПУБЛИКАСЫ

ҰЛТТЫҚ ҒЫЛЫМ АКАДЕМИЯСЫНЫН

АБАЙ АТЫНДАҒЫ ҚАЗАҚ ҰЛТТЫҚ

ПЕДАГОГИКАЛЫҚ УНИВЕРСИТЕТІНІҢ

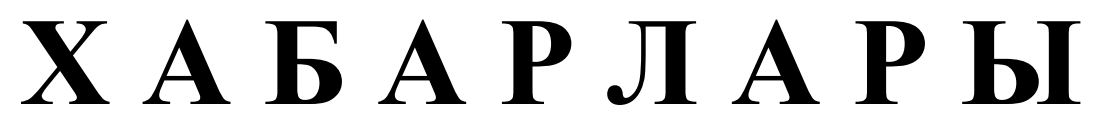

\section{ИЗВЕСТИЯ}

НАЦИОНАЛЬНОЙ АКАДЕМИИ НАУК РЕСПУБЛИКИ КАЗАХСТАН

КАЗАХСКИЙ НАЦИОНАЛЬНЫЙ

ПЕДАГОГИЧЕСКИЙ УНИВЕРСИТЕТ ИМ. АБАЯ

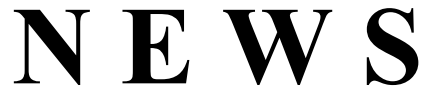

OF THE NATIONAL ACADEMY OF SCIENCES OF THE REPUBLIC OF KAZAKHSTAN

ABAY KAZAKH NATIONAL PEDAGOGICAL UNIVERSITY

ҚОҒАМДЫҚ ЖӘНЕ ГУМАНИТАРЛЫҚ ҒЫЛЫМДАР СЕРИЯСЫ

СЕРИЯ ОБЩЕСТВЕННЫХ И ГУМАНИТАРНЫХ НАУК

$\checkmark$

SERIES OF SOCIAL AND HUMAN SCIENCES

$$
5 \text { (321) }
$$

КЫРКУЙЕК - КАЗАН 2018 ж.

СЕНТЯБРЬ - ОКТЯБРЬ 2018 Г.

SEPTEMBER - OCTOBER 2018

1962 ЖЫЛДЫҢ ҚАНТАР АЙЫНАН ШЫҒА БАСТАҒАН

ИЗДАЕТСЯ С ЯНВАРЯ 1962 ГОДА

PUBLISHED SINCE JANUARY 1962

ЖЫЛЫНА 6 РЕТ ШЫҒАДЫ

ВЫХОДИТ 6 РАЗ В ГОД

PUBLISHED 6 TIMES A YEAR 
Ба с ре дактор

ҚР ҰҒА кұрметті мүшесі

Балықбаев Т.O.

Р е д а ц и я а лқ а сы:

экон. ғ. докторы, проф., ҚР ҰҒА академигі Баймұратов У.Б.; тарих ғ. докторы, проф., ҚР ҰҒА академигі Байпақов К.М.; филос. ғ.докторы, проф., ҚР ҰҒА академигі Есім Г.Е.; фил. ғ. докторы,, проф., ҚР ҰҒА академигі Қирабаев С.С.; эк. ғ. докторы, проф., ҚР ҰҒА академигі Кошанов А.К.; эк.ғ. докторы, проф., ҚР ҰҒА академигі Нәрібаев К.Н. (бас редактордың орынбасары); филос. ғ.докторы, проф., ҚР ҰҒА академигі Нысанбаев А.Н.; заң ғ. докторы, проф., ҚР ҰҒА академигі Сәбікенов С.Н.; заң ғ. докторы, проф., ҚР ҰҒА академигі Сүлейменов М.К.; эк. ғ. докторы, проф., ҚР ҰҒА академигі Сатыбалдин С.С.; тарих ғ. докторы, проф., ҚР ҰҒА академик Әбжанов Х.М.; тарих ғ. докторы, проф., ҚР ҰҒА корр. мүшесі Әбусеитова М.Х.; тарих ғ. докторы, проф., ҚР ҰҒА академик Байтанаев Б.А.; филол. ғ. докторы, проф., ҚР ҰҒА корр. мүшесі Жақып Б.А.; фил. ғ. докторы, проф., академик НАН РК Қалижанов У.К.; филол. ғ. докторы, проф., ҚР ҰҒА академик Қамзабекұлы Д.; тарих ғ. докторы, проф., ҚР ҰҒА академик Қожамжарова Д.П.; тарих ғ. докторы, проф., ҚР ҰҒА академик Койгелдиев М.К.; фил. ғ. докторы, проф., ҚР ҰҒА корр. мүшесі Кұрманбайұлы Ш.; тарих ғ. докторы, проф., ҚР ҰҒА корр. мүшесі Таймағанбетов Ж.К.; социол. ғ. докторы, проф., ҚР ҰҒА корр. мүшесі Шәукенова 3.К.; фил. ғ. докторы, проф., КР ҰҒА корр. мүшесі Дербісәлі А.; саяси. ғ. докторы, проф., Бижанов А.К., тарих ғ. докторы, проф., Кабульдинов 3.Е.; фил. ғ. докторы, проф., ҚР ҰҒА корр мүшесі Қажыбек Е.3.

\section{Р едакция ке н е с i:}

Молдова Республикасының ҰҒА академигі Белостечник Г. (Молдова); Әзірбайжан ҰҒА академигі Велиханлы Н. (Азербайджан); Тәжікстан ҰҒА академигі Назаров Т.Н. (Тәжікстан); Молдова Республикасының ҰҒА академигі Рошка А. (Молдова); Молдова Республикасының ҰҒА академигі Руснак Г. (Молдова); Әзірбайжан ҰҒА корр. мүшесі Мурадов Ш. (Әзірбайжан); Әзірбайжан ҰҒА корр. мүшесі Сафарова 3. (Әзірбайжан); э. ғ. д., проф. Василенко В.Н. (Украина); заң ғ. докт., проф. Устименко В.А. (Украина)

«Қазақстан Республикасы Ұлттық ғылым академиясының Хабарлары. Қоғамдық және гуманитарлық ғылымдар сериясы». ISSN 2224-5294

Меншіктенуші: «Қазақстан Республикасының Ұлттық ғылым академиясы» РҚБ (Алматы қ.)

Қазақстан республикасының Мәдениет пен ақпарат министрлігінің Ақпарат және мұрағат комитетінде 30.04.2010 ж. берілген № 10894-Ж мерзімдік басылым тіркеуіне қойылу туралы куәлік

Мерзімділігі: жылына 6 рет.

Тиражы: 500 дана.

Редакцияның мекенжайы: 050010, Алматы қ., Шевченко көш., 28, 219 бөл., 220, тел.: 272-13-19, 272-13-18, http://nauka-nanrk.kz. social-human.kz

(C) Қазақстан Республикасының Ұлттық ғылым академиясы, 2018

Типографияның мекенжайы: «Аруна» ЖК, Алматы қ., Муратбаева көш., 75. 
Главный редакто $p$

Почетный член НАН РК

T.O. Балыкбаев

Р е дак ци онн а я коллег и я:

докт. экон. Н., проф., академик НАН РК У.Б. Баймуратов; докт. ист. н., проф., академик НАН РК К.М. Байпаков; докт. филос. Н., проф., академик НАН РК Г.Е. Есим; докт. фил. Н., проф., академик НАН РК С.С. Кирабаев; докт. экон. Н., проф., академик НАН РК А.К. Кошанов; докт. экон. Н., проф., академик НАН РК К.Н. Нарибаев (заместитель главного редактора); докт. филос. н., проф., академик НАН РК А.Н. Нысанбаев; докт. юр. Н., проф., академик НАН РК С.Н. Сабикенов; докт. юр. н., проф., академик НАН РК М.К. Сулейменов; докт. экон. Н., проф., академик НАН РК С.С. Сатубалдин; докт. ист. н., проф., академик НАН РК Х.М. Абжанов; докт. ист. н., проф., чл.-корр. НАН РК М.Х. Абусеитова; докт. ист. н., проф., академик НАН РК Б.А. Байтанаев; докт. фил. н., проф., чл.-корр. НАН РК Б.А. Жакып; докт. фиолол. н., проф., академик НАН РК У.К. Калижанов; докт. фил. н., проф., академик НАН РК Д. Камзабекулы; докт. ист. н., проф., академик НАН РК Д.П. Кожамжарова; докт. ист. н., проф., академик НАН РК М.К. Койгельдиев; докт. филол. н., проф., чл.-корр. НАН РК Ш. Курманбайулы; докт. ист. н., проф., чл.корр. НАН РК Ж.К. Таймаганбетов; докт. социол. н., проф., чл.-корр. НАН РК З.К. Шаукенова; д. филол. н., проф., чл.-корр. НАН РК А. Дербисали; доктор политических наук, проф., Бижанов А.К.; доктор ист. наук, проф., Кабульдинов 3.Е.; доктор филол. н., проф., член-корр. НАН РК Қажыбек Е.3.

Р е дак ци онны й с ов е т

академик НАН Республики Молдова Г. Белостечник (Молдова); академик НАН Азербайджанской Республики Н. Велиханлы (Азербайджан); академик НАН Республики Таджикистан Т.Н. Назаров (Таджикистан); академик НАН Республики Молдова А. Рошка (Молдова); академик НАН Республики Молдова Г. Руснак (Молдова); чл.-корр. НАН Азербайджанской Республики Ш. Мурадов (Азербайджан), член-корр. НАН Азербайджанской Республики 3.Сафарова (Азербайджан); д. э. н., проф. В.Н. Василенко (Украина); д.ю.н., проф. В.А. Устименко (Украина)

Известия Национальной академии наук Республики Казахстан. Серия общественных и гуманитарных наук. ISSN 2224-5294

Собственник: РОО «Национальная академия наук Республики Казахстан» (г. Алматы)

Свидетельство о постановке на учет периодического печатного издания в Комитете информации и архивов

Министерства культуры и информации Республики Казахстан № 10894-Ж, выданное 30.04.2010 г.

Периодичность 6 раз в год

Тираж: 500 экземпляров

Адрес редакции: 050010, г. Алматы, ул. Шевченко, 28, ком. 219, 220, тел. 272-13-19, 272-13-18, www:nauka-nanrk.kz / social-human.kz

(C) Национальная академия наук Республики Казахстан, 2018 г.

Адрес типографии: ИП «Аруна», г. Алматы, ул. Муратбаева, 75

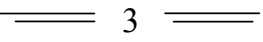


Chief Editor

\section{Honorary member of NAS RK \\ Balykbayev T.O}

Editorial board:

Doctor of economics, prof, academician of NAS RK Baimuratov U.B.; doctor of history, prof, academician of NAS RK Baipakov K.M.; doctor of philosophy, prof, academician of NAS RK Esim G.E.; doctor of philology, prof, academician of NAS RK Kirabayev S.S.; doctor of economics, prof, academician of NAS RK Koshanov A.K.; doctor of economics, prof, academician of NAS RK Naribayev K.N. (deputy editor-in-chief); doctor of philosophy, prof, academician of NAS RK Nyssanbayev A.N.; doctor of law, prof, academician of NAS RK Sabikenov S.N.; doctor of law, prof, academician of NAS RK Suleymenov M.K.; doctor of economy, prof, academician of NAS RK Satybaldin S.S.; doctor of history, prof, academician of NAS RK Abzhanov H.M; doctor of history, prof, corresponding member of NAS RK Abuseitova M.H.; doctor of history, prof, academician of NAS RK Baitanaev B.A.; doctor of philology, prof, corresponding member of NAS RK Zhakyp B.A.; doctor of philology, prof, academician of NAS RK Kalizhanov U.K.; doctor of philology, prof, academician of NAS RK Hamzabekuly D.; doctor of history, prof, academician of NAS RK Kozhamzharova D.P.; doctor of history, prof, academician of NAS RK Koigeldiev M.K.; doctor of philology, prof, corresponding member of NAS RK Kurmanbaiuly Sh.; doctor of history, prof, academician of NAS RK Taimaganbetov J.K.; doctor of sociology, prof, corresponding member of NAS RK Shaukenova Z.K.; doctor of philology, prof, corresponding member of NAS RK Derbisali A.; doctor of political science, prof Bizhanov A.K; doctor of History, prof Kabuldinov Z.E.; doctor of philology, prof, corresponding member of NAS RK Kazhybek E.Z.

\section{Editorial staff:}

Academician NAS Republic of Moldova Belostechnik.G (Moldova); Academician NAS Republic of Azerbaijan Velikhanli N. (Azerbaijan); Academician NAS Republic of Tajikistan Nazarov T.N. (Tajikistan); Academician NAS Republic of Moldova Roshka A. (Moldova) Academician NAS Republic of Moldova Rusnak G. (Moldova); Corresponding member of the NAS Republic of Azerbaijan Muradov Sh. (Azerbaijan); Corresponding member of the NAS Republic of Azerbaijan Safarova Z. (Azerbaijan); Associate professor of Economics Vasilenko V.N. (Ukraine), Associate professor of Law Ustimenko V.A. (Ukraine)

News of the National Academy of Sciences of the Republic of Kazakhstan. Series of Social and Humanities. ISSN 2224-5294

Owner: RPA "National Academy of Sciences of the Republic of Kazakhstan" (Almaty)

The certificate of registration of a periodic printed publication in the Committee of information and archives of the Ministry of culture and information of the Republic of Kazakhstan N 10894-Ж, issued 30.04.2010

Periodicity: 6 times a year

Circulation: 500 copies

Editorial address: 28, Shevchenko str., of. 219, 220, Almaty, 050010, tel. 272-13-19, 272-13-18, www:nauka-nanrk.kz / social-human.kz

(C) National Academy of Sciences of the Republic of Kazakhstan, 2018

Address of printing house: ST "Aruna", 75, Muratbayev str, Almaty 
N E W S

OF THE NATIONAL ACADEMY OF SCIENCES OF THE REPUBLIC OF KAZAKHSTAN

SERIES OF SOCIAL AND HUMAN SCIENCES

ISSN 2224-5294

https://doi.org/10.32014/2018. 2224-5294.12

Volume 5, Number 321 (2018), $68-72$

UDC 378.1: 338.482

A.M. Madisheva, A.S. Bikenova, L.T. Eleusis

Kazakh University of Economics, Finance and International Trade asem_madysheva@mail.ru, a.s.bikenova@mail.ru, lyaila@list.ru

\title{
TOURIST SERVICES IN THE SPHERE OF EDUCATION
}

\begin{abstract}
The authors of the article touch upon the problems of the tourist industry, in particular, the provision of services for their provision to the population, which directly depends on the professional training of personnel for the tourism industry, which is not carried out in the Republic of Kazakhstan at a high level. Managerial and technological activities are characteristic for the staff, which provides a technological sequence of services, coordinates interaction with other technological links (travel agent, reservation manager, restaurant manager). Training of mid-level specialists in Kazakhstan is provided in the system of higher education, graduating bachelors of economics, and in specialized educational institutions that provide secondary education. However, there is no real relationship between education and the tourism industry, which adversely affects the development of tourism in the country.
\end{abstract}

Keywords: tourist services, industry, travel agent, reservation manager, maitre d'hotel, restaurant.

\section{INTRODUCTION}

In the last decade, a new trend has emerged in the field of international tourism - the excess of the increase in the number of travelers to the near abroad and the states of the nearest regions relative to the number of travelers to foreign countries. Some tourism specialists explain this fact by the existing threat of terrorism in many regions of the world, others - the growth in the number of tourist trips per year due to fragmentation of holidays for small parts. Finally, another important trend noted by many experts is the synergetic effect of the interaction of such factors as competition and competitive advantages of countries, information and web technologies, the system of world air travel routes, the development of tour-operator services, and private political and social conditions for the development of states. All three noted trends play a decisive role in the formation and implementation of state policy in the field of international tourism. Tougher competition in the market of tourist demand and supply is a serious problem on the way of development of international tourism.

\section{MAIN PART}

This is reflected in the emergence of a large number of states with ambitious plans to attract international tourists, as well as oversaturation of the market with common types of tourist products, for example, beach holidays or shopping tours. This problem requires from the states, trying to save the tourist attractiveness, the implementation of a number of concerted actions. Among them: the balance between tourist demand and supply; design of products and services in the field of international tourism in accordance with the concepts of "sustainable tourism", "affordable tourism" and "responsible tourism"; ensuring long-term investments in international tourism; formation of a clear and effective state strategy for the development of the national recreation and tourism industry with flexible and operational mechanisms for making managerial decisions. The rapid development of information technology and the reduction in the cost of tourist trips in comparison with the increase in the incomes of the population contribute to the growth of the number of travelers, contributing to the worldwide process of globalization. Its negative characteristic is the uniformity and unification of services. In this regard, a significant number of travelers choose trips to tourist destinations, providing a large number of entertainment and highly comfortable conditions for recreation. 
Enterprises of the tourism industry produce specific tourist services, which are required by the work of tour operators, forming a tourist product from the whole variety of tourist services. Therefore, we can say that the tourism industry is a resource base for the activities of tour operators.

On the other hand, the quality of a tourist product is defined as a combination of the properties of tourism services and service processes, to meet the conditioned or proposed needs of tourists. The quality of the tourist product is characterized by the quality of services and the culture of service. Obligatory requirements to the quality of tourist services:

- $\quad$ safety of life and health;

- Guarantee of providing services in accordance with the voucher;

- $\quad$ safety of property of tourists and excursionists;

- $\quad$ protection of the environment.

At the same time, the quality criterion is expressed through a system of indicators reflecting various types of tourist service activities.

From the above it follows that a wide range of services in the sphere of tourism requires both the universality of knowledge of specialists working in this field and management skills at various levels: from the animator to the head of the hotel complex or transport enterprise. Therefore, as the tourism business develops, the greatest need, at least in the last decade, arises in the training of economics and management specialists for the tourism industry.

The requirements for a modern specialist in the tourism industry presuppose, above all, high professionalism and competence. Sometimes theorists and practitioners perceive these concepts differently. In one case it is a highly qualified specialist, in the other case it is a good organizer. And always on the first place are put forward independence, initiative, enterprise, creative thinking, readiness for reasonable risk.

In addition, a specialist in the tourism field must thoroughly know the business, be a professional in it; think strategically; constantly extract new information; to possess high moral qualities; be exceptionally honest. At the same time, the manager must have in-depth knowledge in the field of excursion theory and methodology; know the basics of psychology, pedagogy and excursion propaganda; to have oratorical art, must be able to form intuitions - the ability to grasp the truth by direct discretion without justification with the help of evidence. [2]

The tourism market in Kazakhstan is developing at a steady pace. But, so that it becomes civilized, competent specialists are needed, as we have already said. Educational institutions for the training of tourist personnel and advanced training courses in our country is enough. But does the level of knowledge of their graduates correspond to the requirements set by the tourism industry? If we compare Kazakhstan and the European model of education in tourism, then we can say that the advantage of European models of professional training for the tourism industry is: a significant part of the study time is designed to gain practical skills in practical classes, practices and internships in the industry; emphasis on the formation of students in the psychology of customer service; close cooperation of educational institutions with the industry; high student mobility. Most of the schools of tourism and hospitality in Europe are open on the basis of operating hotels. Students live in the same place, which allows them to receive practical professional skills in an environment close to reality. Such experience is of undoubted interest and prospects for improving the quality of training in the Republic of Kazakhstan.

In comparison with the Kazakh education, the European one provides for carrying out production practices in the amount of 50 to $70 \%$ of the study time. Attention is paid to the experience of training personnel in the United States, where specialized departments (recruitment agencies) are formed on the basis of educational institutions, connected by a single information system with tourism industry enterprises that regularly monitor labor market needs, employ young specialists and adjust the recruitment of entrants in profile specialties. The advantage of the American model is also: close integration with public professional organizations; deep study of general theoretical positions in the field of management; the availability of a large number of various courses for advanced training and retraining, etc. Based on the analysis of domestic and foreign experience in the training of personnel, it is possible to propose an approach to the modernization of the Kazakh system of training personnel for the tourism industry, the main provisions of which are:

- creation of a monitoring system for educational services in this segment of the labor market; 
- strengthening the relationship of educational institutions with industry enterprises;

- intensive courses of advanced training and retraining, especially for specialists with primary and secondary vocational education;

- reorganization of the system of retraining and advanced training of the faculty, through the creation of unified centers for retraining on the basis of the leading universities of the tourism industry. [3] In the system of professional training of personnel for the tourist industry in Kazakhstan, there are three educational levels:

- $\quad$ The highest level is institutional and managerial.

- $\quad$ The middle level is managerial and technological.

- Initial or lower level (technologically-executive).

The highest (institutional and managerial) level presupposes the training of managers who determine the directions and tasks of the work, strategy, tactics of the industry, a separate enterprise (tour manager, hotel manager, manager of marketing activities in tourism, etc.). Specialized training of specialists of this level is usually carried out in higher educational institutions.

In turn, the professional training of personnel for the tourist industry, carried out at an average level, is aimed at training managerial and technological personnel. Managerial and technological activities are characteristic for the staff, which provides a technological sequence of services, coordinates interaction with other technological links (travel agent, reservation manager, restaurant manager). The training of mid-level specialists in Kazakhstan is provided both in the higher education system that produces bachelors in economics, and in specialized educational institutions that provide secondary education.

Currently, we also have specialized colleges that train mid-level specialists for tourism. However, in practice, the knowledge that graduates of colleges possess is often not enough to start working in tourist companies, hotels, restaurants, etc. [4]

And, finally, the initial or the lowest level (technologically-executive) carries out the training of personnel who perform specific tasks and ensure the satisfaction of individual tourist needs, or the implementation of a separate type of service. Training of such specialists is provided by various centers, schools and courses, teaching employees of mass professions - waiters, cooks, sports instructors, etc.

The Concept for the Development of the Tourism Industry of the Republic of Kazakhstan until 2020 states that for the implementation of large tourism projects and the subsequent management of the created infrastructure facilities, tourist resources, there is a need for top tourism specialists and managers of the tourism industry. In this regard, it is proposed to consider the possibility of cooperation with Nazarbayev University.

- An important condition for the successful development of the recreation and tourism sector in the capital of Kazakhstan is the sufficiency of the special infrastructure and the availability of not complex facilities or services, but complex products - tour packages and programs. They should include not only the objects of the show, but also their thematic fullness, as well as the following components: a developed tourist infrastructure (accommodation, food, transportation for tourists) and professional services; availability of transport infrastructure, providing convenient access to the facility, comfortable sightseeing routes; high level of excursion service; a high-quality integrated product with the presence of personnel who are qualified with a wide range of knowledge and developed communication skills that make visiting the site as interesting and cognitive as possible for the tourist; qualitative, diverse and distinctive, including branded, souvenir products [17].

The main problems hampering the development of the tourism industry in Kazakhstan include: disunity of participants in the tourism market;

- - insufficiently developed regulatory framework;

- - Inadequately high prices for accommodation with a fairly low level of development of tourist infrastructure.

A necessary condition for eliminating these problems and ensuring sustainable development of the tourism industry is the support of tourism at the state level.

Studies of the unsustainable development of tourism at the local level in developing countries (the reference to Urgup in the region of Cappadocia, Turkey), factors that contribute to the unsustainable development of tourism, are beyond the control of local residents and authorities. These factors are largely related to national issues, including economic policy, the importance of tourism for the country, the 
relationship between decision-makers (ministers, department heads, etc.) and related international tour operators in the international tourism system. The main conclusion of the study is that the achievement of sustainable development of tourism at the local level in developing countries requires strong political decisions, control over their implementation and cooperation of international tour operators and local travel agencies [7].

Analyzing the policies and activities carried out in the field of tourism regulation in foreign countries, the paper highlights some of the principal approaches common to all the most developed countries in the tourist sphere:

- the main role in regulating the development of tourism of public authorities, with the creation at the national level of a single governing body, up to giving it the status of a ministry;

- the basis for regulating tourism are long-term strategies for sustainable tourism development and tourism development programs developed on their basis in the regions or individual components of the tour-stria;

- significant role of tourism in the implementation of social policy: both in the creation of additional jobs, and in the sphere of social protection of low-income strata of the population, giving priority to the development of social tourism;

- stimulating off-season tourism, in order to equalize tourist arrivals and, accordingly, reduce pressure on infrastructure - airports, airlines, land transport communications, accommodation facilities;

- manifestation by the bodies of state regulation of tourism of the increased interest in research and development in this sphere, analysis of development trends, use of marketing technologies;

- the strengthening of security requirements in connection with the frequent attacks of extremists of different persuasions;

- application and use of the newest technologies as a means of increasing the competitiveness of their own tourist product and increasing the degree of accessibility, the efficiency of the use of tourist resources;

- a close interconnection of activities for the development of tourism and measures to protect the environment, cultural and historical heritage.

\section{LIST OF USED LITERATURE:}

The inflated prices for tourist accommodation are a consequence of the inefficient tax policy of the state. To eliminate this problem and adjust the cost of services to average European prices, it is necessary to introduce local tourist rents in the subjects of the Republic of Kazakhstan, levied from tourism enterprises, by restructuring other taxes. The collected funds can be invested in the development of tourism infrastructure and recreational resources.

The arsenal of methods used to regulate and stimulate the development of the tourism industry in different countries is uniform in nature and includes economic, legal, social, organizational, cultural, and environmental practices used in the practice of all countries. However, the specific tool for implementing these methods varies and varies considerably across countries.

УДК 378.1:338.482

\section{А.М. Мадышева, А.С. Бикенова, Л.Т. Елеусиз}

Казахский университет экономики, финансов и международной торговли

\section{ТУРИСТСКИЕ УСЛУГИ В СФЕРЕ ОБРАЗОВАНИЯ}

Аннотация. Авторы статьи задевают проблемы туристской отрасли, в частности услуг их предоставления населению, что напрямую зависит от профессиональной подготовки кадров для туристской индустрии, которая в РК осуществлятся на не высоком уровне. Управленческо-технологическая деятельность характерна для персонала, который обеспечивает технологическую последовательность обслуживания, согласовывает взаимодействие с другими технологическими звеньями. Подготовка специалистов среднего уровня в Казахстане обеспечивается в системе высшего образования, выпускающих бакалавров экономики, так и в специализированных учебных заведениях, дающих среднее образование. 
Однако, отсутствует реальная взаимосвязь образования и отрасли туристских услуг, что отрицательно сказывается на развитии туризма в стране.

Ключевые слова: туристские услуги, индустрия, турагент, менеджер по резервированию мест, метрдотель, ресторан

УДК 378.1:338.482

\section{А.М. Мадышева, А.С. Бикенова, Л.Т. Елеусиз}

Қазақ экономика, қаржы және халықаралық сауда университеті

\section{БІЛІМ САЛАСЫНДАҒЫ ТУРИСТІК ҚЫЗМЕТТЕР}

Аннотация. Мақаланың авторлары туристік саланың проблемаларына, атап айтқанда, Қазақстан Республикасында жүзеге асырылмайтын туризм индустриясы үшін кадрларды кәсіби даярлауға тікелей тәуелді болатын халыққа қызмет көрсету бойынша қызметтер көрсетуді жоғары деңгейде қолданады. Қызмет көрсетудің технологиялық реттілігін қамтамасыз ететін, басқа технологиялық байланыстармен өзара ісқимыл жасайтын қызметкерлерді басқару және технологиялық қызмет тән. Қазақстандағы орта деңгейдегі мамандарды даярлау жоғары білім беру жүйесінде, экономика бакалаврларын бітіріп, орта білім беретін мамандандырылған оқу орындарында қамтамасыз етіледі. Дегенмен, білім беру мен туризм индустриясының арасындағы нақты қарым-қатынас жоқ, бұл елдегі туризмнің дамуына теріс әсер етеді.

Түйін сөздер: туристік қызметтер, индустрия, турагент, брондау менеджері, қонақ үй, мейрамхана

Information about author:

Madisheva A.M. - Kazakh University of Economics, Finance and International Trade, asem madysheva@mail.ru, https://orcid.org/0000-0003-2193-9570

Bikenova A.S. - Kazakh University of Economics, Finance and International Trade, a.s.bikenova@mail.ru, https://orcid.org/0000-0002-6540-6373

Eleusis L.T. - Kazakh University of Economics, Finance and International Trade, lyaila@list.ru, https://orcid.org/0000$\underline{0002-0394-6518}$ 


\section{МАЗМҰНЫ}

Алтыбаева С.М., Савындыков Е.С. Көркем мәтін құрылымындағы мифопоэтикалық модельдеу және мәдени код...... 5 Сембиева Л.М., Мажитов Д.М., Карпиикая М.Е., Хамитова Д.М. Экономиканы жаңғырту жағдайындағы ЕАЭО елдерінің монетарлық жүесінін өзгеруі .....

Құлсариева А.Т., Султанова М.Э., Шайгозова Ж.Н. Фольклор және сәйкестілік: Қазақстанның қазіргі заманғы

мәдениетіндегі тарих, жады және аңыз шығармашылығы ........................................................................................... 19

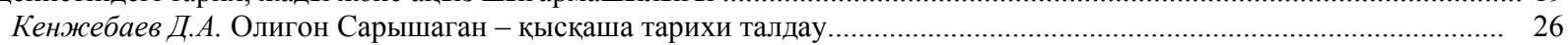

АбдулинаГ.А., БазарбаевА.Г. Ұйымдардағы адам ресурстарын басқарудың заманауи тұжырымдамалары................ 33

Авыбаев А.Н., Адибаева А.К. Геноцид туралы БҰҰ Конвенциясының қатысушы мемлекеттердің қылмыстық

заңнамаларындағы имплементациялық тетіктері: жалпы салыстырмалы талдау............................................................ 39

Ахметжанов Б., Тәжібекова К.Б., Шаметова А.А. Қазақстан көлік өнеркәсіптің дамуын талдау............................. 44

Аюпова 3.К., Құсайынов Д.Ө. Тәуелсіздік жағдайындағы қазақстан республикасының конституциялық-құқықтық

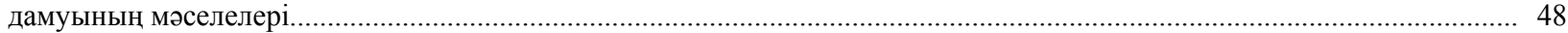

Нурпеисова А.А., Рей И.Ю., Бижанов Д.Т., Тлеужанова Д.А. Инновациялық өндірісді жасаудың процесін

бақылауының негізгі элементтері

Гиздатов Г.Г. Қазақстандық дискурсының құрылымы психолингвистиякалық зерттеу .

Ищанова Р.К. Мемлекеттік шығындарды басқару - мемлекеттің қаржылық тұрақтылығын қамтамасыз ету.............. 64

Мадышева А.М. Бикенова А.С., Елеусиз Л.Т. Білім саласындағы туристік қызметтер............................................. 68

Ескалиева А. Ж., Баймуханова М.Т., Ахмурзина Д.О. Әлеуметтік сала адам капиталының сапасын қолдаудың

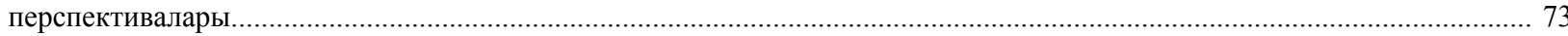

Мархаева Б.А., Козбахова Д.Л. Жауапкершілік орталық және трансферттік баға белгілеу............................................ 79

Сабирова Р.К., Утепкалиева К.М., Кабаков С.Б. Қазақстандағы ауыл шаруашылығы экономикасының

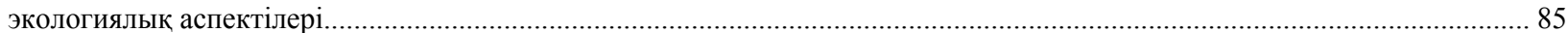

Тлесова Э., Хойч А., Кураш Н. Қазақстан республикасының ғылыми инновациялық потенциясы және оның

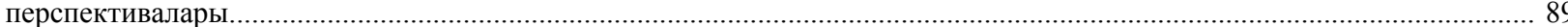

Хамитхан Н. Қазақстандағы банктік қызметтердің сапасын жақсарту жағдайында банкаралык басекелестік............ 95

Шалдарбеков Қ.Б., Муханова Г.С., Нурмухамбетова 3.С. Аймақтарды дамыту бағдарламаларын жүзеге асырудағы жобалық басқаруды қолданудың шетелдік тәжірибесі

КаратаеваА.М., Бердиярова Ж.С. Мемлекеттік қызметшінің әдептік мәдениеті және құқықтық мәдениеті

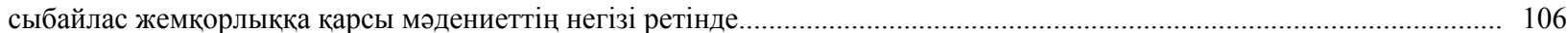

Алдабергенова А.А. Абсурд әдебиетін аударудың лингвомәдени аспектілері ................................................... 113

Стукач В. Ф., Байдалинова А. С., Сандыбаева Б. А. Қазақстанның қаржылық қауіпсіздігі......................................... 119

Баймаханова Д.М., Оспанова Д.А. Конституциялық-құқықтық сана - конституционализмнің маңызды

компоненті ретінде және оның адам құқықтары мәселелерін шешудегі рөлі................................................................. 126

Имангожина 3.А. Сланцевая революция: глобальный тренд на мировом энергетическом рынке............................. 137

Ракаева А.Н., Жуматаева Б.А., Успамбаева М.К., Доскалиева Б.Б. Экологиялық есеп қазақстандағы кәсіпорын экономикасының даму кезеңі ретінде

Нуржанова Г.И. Экономиканың аграрлық секторындағы еңбек әлеуетіне демографиялық фактордың әсері............ 147

Оспанова Д.А., Баймаханова Д.М. Қазақстан Республикасының кибер кеңістігін дамыту жағдайында мемлекеттік қызметтерді цифрландыруда әкімшілік-құқықтық қамтамасыз ету ................................................................................... 152

Pblсnекова М.О., Тлесова Э.Б., Хаитбаева Ф.К. Қазақстандағы тұрғын үй-коммуналдық шаруашылық қызметін

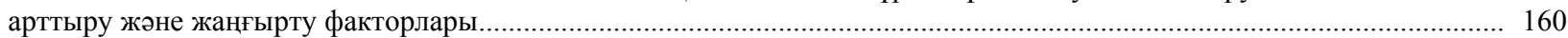

Султанова Г. Т. Аграрлық сектордың экспорттық әлеуетін дамытуға бағытталған үрдістер мен басымдықтар........ 166 


\section{СОДЕРЖАНИЕ}

Алтыбаева С.М., Сагындыков Е.С. Культурный код и мифопоэтическое моделирование в структуре художественного текста.

Сембиева Л.М., Мажитов Д.М., Карпиикая М.Е., Хамитова Д.М. Трансформация монетарной системы стран

ЕАЭС в условиях модернизации экономики.............................................................................................................

Кулсариева А.T., Султанова М.Э., Шайгозова Ж.Н. Фольклор и идентичность: история, память и мифотворчество

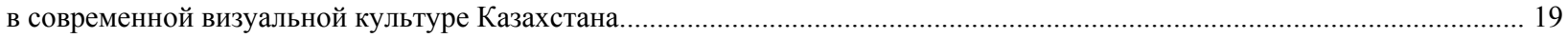

Кенжебаев Д.А. Полигон Сарышаган - краткий исторический анализ................................................................ 26

Абдулина Г.А., БазарбаевА.Г. Современные концепции управления человеческми ресурсами в организациях........... 33

Агыбаев А.Н., Адибаева А.К. Имплементационные механизмы Конвенции ООН о геноциде в уголовных

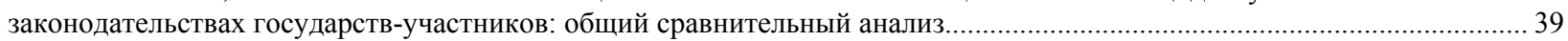

Ахметжанов Б., Тажибекова К.Б., Шаметова А.А. Анализ развития угольной промышленности Казахстана........... 44

Аюпова 3.К., Кусаинов Д.У.Проблемы конституционно-правового развития республики Казахстан в условиях

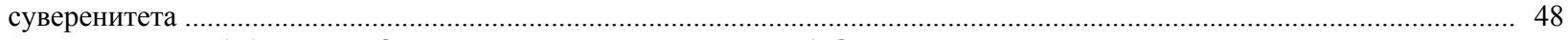

Нурпеисова А.А., Рей И.Ю., Бижанов Д.Т., Тлеужанова Д.А. Основные элементы управления процессом создания

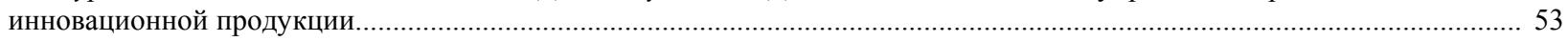

Гиздатов Г.Г. Психолингвистическое исследование концептов казахстанского дискурса...................................... 57

Ищанова Р.К. Управление государственными расходами - как обеспечение финансовой устойчивости государства. 64

Мадымева А.М. Бикенова А.С., Елеусиз Л.Т. Туристские услуги в сфере образования........................................... 68

Ескалиева А. Ж., Баймуханова М.Т., Ахмурзина Д.О. Перспективы усиления качества человеческого капитала

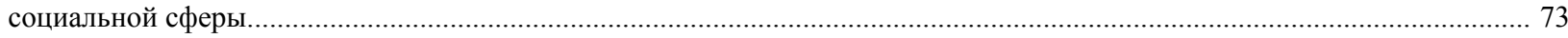

Мархаева Б.А., Козбахова Д.Л. Центр ответственности и трансфертное ценообразование..................................... 79

Сабирова Р.К., Утепкалиева К.М., Кабаков С.Б. Экологические аспекты экономики сельского хозяйства

в Казахстане........................................... 85

Тлесова Э., Хойч А., Кураш Н. Научно-инновационный потенциал республики Казкастан и его перспективы............ 89

Хамитхан Н. Межбанковская конкуренция в условиях повышения качества банковских услуг в Казахстане.............. 95

Шалдарбеков К.Б., Муханова Г.С., Нурмухамбетова 3.С. Зарубежный опыт применения проектного управления

при реализации программ развития регионов

Каратаева А.М., Бердиярова Ж.С. Этическая культура и правовая культура государственных служащих

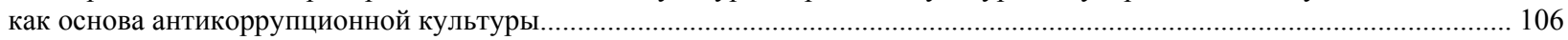

Алдабергенова А.А. Лингвокультурологические аспекты перевода литературы абсурда.......................................... 113

Стукач В. Ф., Байдалинова А. С., Сандыбаева Б. А. Казахстанская финансовая безопасность.................................... 119

Баймаханова Д.М., Оспанова Д.А. Конституционно-правовое сознание как важный компонент конституционализма

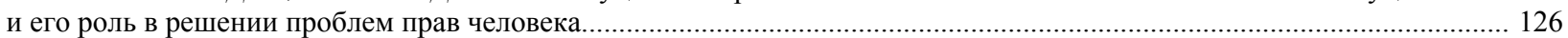

Имангожина 3.A. Сланцевая революция: глобальный тренд на мировом энергетическом рынке............................. 137

Ракаева А.Н., Жуматаева Б.А., Успамбаева М.К., Доскалиева Б.Б. Экологический учет как ступень развития

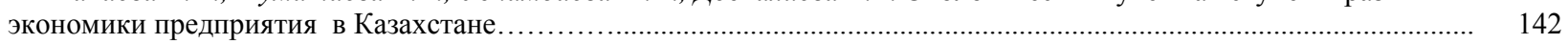

Нуржанова Г.И. Влияние демографического фактора на трудовой потенциал аграрного сектора экономики............ 147

Оспанова Д.А., Баймаханова Д.М. Административно-правовое обеспечение цифровизации государственных услуг

в условиях развития кибер пронстранства республики Казахстан..

Pыспекова М.О., Тлесова Э.Б., Хаитбаева Ф.К. Факторы инновационной модернизации и совершенствования

деятельности жилищно-коммунального хозяйства в Казахстане.

160

Султанова Г. Т. Тенденции и приоритеты развития экспортного потенциала аграрного сектора................................ 166 


\section{CONTENTS}

Altybayeva S.M., Sagyndykov E.S. Cultural code and myth poetic modeling in the structure of the artistic text..................... 5 Sembiyeva L.M., Mazhitov D.M., Karpitskaya M.E., Khamitova D.M. Transformation of the monetary system of the eurasian economic UNION countries in the conditions of modernization of the economy......

Kulsarieva A.T., Sultanova M.E., Shaigozova Zh.N. Folklore and identity: history, memory and myth-making in the modern

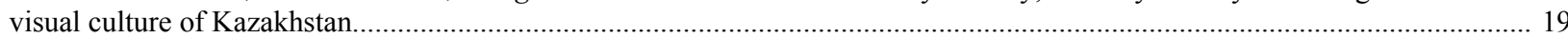

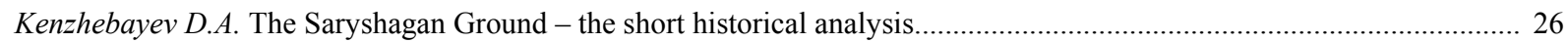

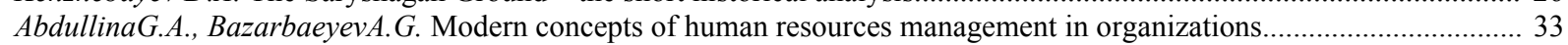

Agybayev A.N., Adibayeva A.K. Implementing mechanisms of the UN Convention on genocide in the criminal legislation

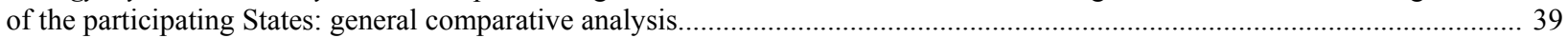

Akhmetzhanov B., Tazhibekova K.B, Shametova A.A. Analysis of development of the coal industry of Kazakhstan.............. 44 Ayupova Z.K., Kussainov D.U. Problems of constitutional and legal development of the republic of kazakhstan in the conditions of sovereignty......

Nurpeisova A.A., Rey I.Yu., Bizhanov D.T., Tleuzhanova D.A. Main elements of managing the process of creating innovation production.

Gizdatov G.G. Psycholinguistic study of the concepts of Kazakhstar

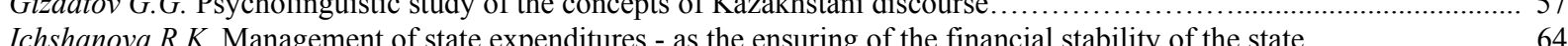

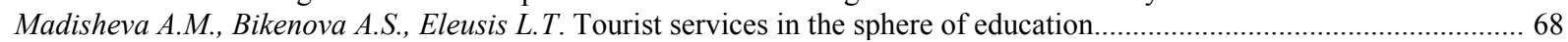

Eskalieva A. Zh., Baymukhanova M.T., Ahmurzina D.O. Perspectives of strengthening the quality of the human capital

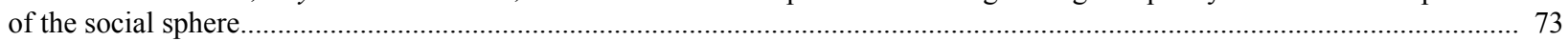

Markhayeva B.A., Kozbakhova D.L. A responsibility center and transfer pricing ................................................. 79

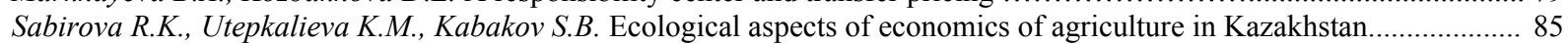

Tlessova E., Khoich A., Kurash N. Scientific innovation potential of the republic of Kazkahstan and its perspectives........ 89

Hamitkhan $N$. Interbank competition in conditions of improving the quality of banking services in Kazakhstan.................. 95

Shaldarbekov K., Mukhanova G., Nurmukhambetova Z. International practices in project management in implementing

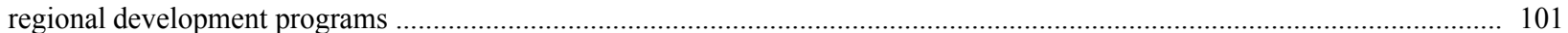

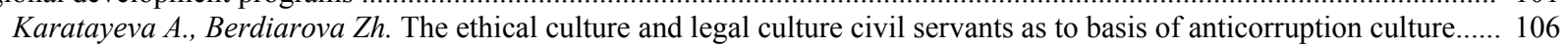

Aldabergenova A.A. Linguocultural aspects of translation of absurd literature.............................................................. 113

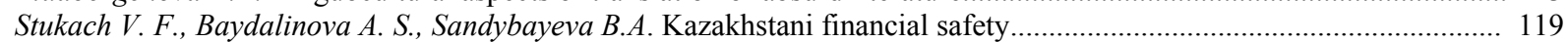

Baimakhanova D.M., Ospanova D.A. Constitutional and legal consciousness as an important component of constitutionalism

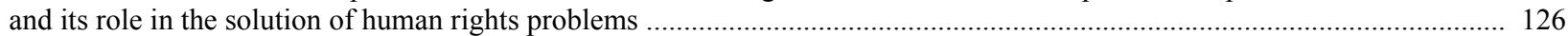

Imangozhina Z.A. Shale gas revolution: global trend in the world energy market..................................................... 137

Rakaeva A.N., Zhumataeva B.A., Uspanbayeva M.K., B.B.Doskalieva. Level of ecological report development in the economic of Kazakhstan's companies.

Nurzhanova G.I. Impact of demographic factors on labor potential of economy's agricultural sector

Ospanova D.A., Baimakhanova D.M. Administrative and legal support of digitalization of public services in the context of the development of cyber space in the republic of Kazakhstan....

Ryspekova M.O., Tlessova E.B., Khaitbayeva F. Factors of innovative modernization and improvement of activity

of housing and communal services in Kazakhstan.

Sultanova G. T. Trends and priorities for the development of export potential of the agrarian sector. 


\title{
PUBLICATION ETHICS AND PUBLICATION MALPRACTICE IN THE JOURNALS OF THE NATIONAL ACADEMY OF SCIENCES OF THE REPUBLIC OF KAZAKHSTAN
}

For information on Ethics in publishing and Ethical guidelines for journal publication see http://www.elsevier.com/publishingethics and http://www.elsevier.com/journal-authors/ethics.

Submission of an article to the National Academy of Sciences of the Republic of Kazakhstan implies that the work described has not been published previously (except in the form of an abstract or as part of a published lecture or academic thesis or as an electronic preprint, see http://www.elsevier.com/postingpolicy), that it is not under consideration for publication elsewhere, that its publication is approved by all authors and tacitly or explicitly by the responsible authorities where the work was carried out, and that, if accepted, it will not be published elsewhere in the same form, in English or in any other language, including electronically without the written consent of the copyrightholder. In particular, translations into English of papers already published in another language are not accepted.

No other forms of scientific misconduct are allowed, such as plagiarism, falsification, fraudulent data, incorrect interpretation of other works, incorrect citations, etc. The National Academy of Sciences of the Republic of Kazakhstan follows the Code of Conduct of the Committee on Publication Ethics (COPE), and follows the COPE Flowcharts for Resolving Cases of Suspected Misconduct (http://publicationethics.org/files/u2/New Code.pdf). To verify originality, your article may be checked by the originality detection service Cross Check http://www.elsevier.com/editors/plagdetect.

The authors are obliged to participate in peer review process and be ready to provide corrections, clarifications, retractions and apologies when needed. All authors of a paper should have significantly contributed to the research.

The reviewers should provide objective judgments and should point out relevant published works which are not yet cited. Reviewed articles should be treated confidentially. The reviewers will be chosen in such a way that there is no conflict of interests with respect to the research, the authors and/or the research funders.

The editors have complete responsibility and authority to reject or accept a paper, and they will only accept a paper when reasonably certain. They will preserve anonymity of reviewers and promote publication of corrections, clarifications, retractions and apologies when needed. The acceptance of a paper automatically implies the copyright transfer to the National Academy of sciences of the Republic of Kazakhstan.

The Editorial Board of the National Academy of sciences of the Republic of Kazakhstan will monitor and safeguard publishing ethics.

Правила оформления статьи для публикации в журнале смотреть на сайте:

$$
\begin{gathered}
\text { www:nauka-nanrk.kz } \\
\text { social-human.kz }
\end{gathered}
$$

\author{
Редакторы М.С. Ахметова, Т.А. Апендиев, Д.С. Аленов \\ Верстка на компьютере А.М. Кульгинбаевой \\ Подписано в печать 10.10.2018 \\ Формат 60x881/8. Бумага офсетная. Печать - ризограф. \\ 11,6 п.л. Тираж 500. Заказ 5.
}

